\title{
KOMPARASI POLIGAMI DAN MONOGAMI PERSPEKTIF HUKUM ISLAM
}

\author{
Feny Dyah Aprillia, Vivien Indrawati Setya \\ Mahasiswa Pascasarjana dan Sarjana Institut Agama Islam Negeri \\ (IAIN) Jember | fenydyahapril@gmail.com \\ DOI: https://doi.org/10.35719/ijl.v1io1.77
}

\begin{abstract}
Islam came to the surface of the earth by bringing some shari'a or order of life for humans, so that their lives are safe and happy in the world until the hereafter. Including those brought by Islam through the Prophet Muhammad. in the form of marriage law. Marriage is sunnatullah where men need a female companion and vice versa. The companion referred to here is a companion as a legal husband and wife who are bound by the 'aqdun nikah bond according to the Islamic order. But in reality, the practice of marriage that occurs at this time has experienced dynamics and variations in the arguments of the fuqaha 'ulama, especially regarding the permissibility of a husband to be polygamous or monogamous. According to some scholars, men are allowed to marry more than one woman on condition that they are able to be fair to their wives, while according to other scholars, polygamy is not legal because it is impossible to achieve a fair attitude, especially fairness with feelings.
\end{abstract}

Keywords: Marriage, polygamy, monogamy

Abstrak: Islam datang ke permukaan bumi dengan membawa beberapa syariat atau tatanan hidup bagi manusia, agar hidupnya selamat dan bahagia dunia sampai akhirat. Termasuk yang dibawa oleh Islam melalui Nabi Muhammad Saw. berupa syariat pernikahan. Pernikahan adalah sunnatullah dimana lakilaki membutuhkan pendamping perempuan begitu pula sebaliknya. Pendamping yang dimaksud di sini adalah pendamping sebagai suami istri yang sah yang diikat oleh ikatan 'aqdun nikah menurut tatanan Islam. Namun pada 
kenyataannya, praktik menikah yang terjadi pada saat ini telah mengalami dinamika dan variasi argumentasi dari para ulama fuqaha', khusunya terkait diperbolehkannya seseorang suami untuk berpoligami atau monogami. Menurut sebagian ulama, laki-laki diperbolehkan menikahi perempuan lebih dari satu dengan syarat mampu bersikap adil terhadap para istrinya, sedangkan menurut ulama yang lain, berpoligami hukumnya tidak boleh karena sikap adil tidak mungkin dapat tercapai, terutama adil dengan perasaan.

Kata Kunci: Pernikahan, poligami, monogami

\section{Pendahuluan}

Asas perkawinan dalam Islam pada dasarnya adalah monogami. Monos berarti satu dan gomos berarti perkawinan.. Monogami adalah suatu sistem perkawinan dimana hanya mengawini satu istri saja. ${ }^{1}$

Kata "Poligami" berasal dari bahasa Yunani, polus yang artinya banyak dan gamein, yang artinya kawin. Jadi, poligami artinya kawin banyak atau suami beristri banyak atau istri bersuami banyak pada saat yang sama.Secara terminologi, poligami terbagi dua, yakni poligini dan poliandri. Poligini untuk suami yang beristri banyak, sedangkan poliandri adalah istri yang bersuami banyak (lebih dari seorang). ${ }^{2}$

Dalam bahasa Arab, poligami disebut dengan ta'did alzawjah (berbilangnya pasangan). Dalam bahasa Indonesia disebut permaduan dan dalam bahasa Sunda disebut nyandung.Menurut ajaran Islam, yang kemudian disebut dengan syariat Islam (hukum Islam), poligami ditetapkan sebagai perbuatan yang dibolehkan atau mubah. Dengan demikian , meskipun dalam surat An-Nisâ ayat 3 disebutkan

\footnotetext{
1 https://id.scribd.com/document/343228805/makalah-monogami, pada tanggal 9 Oktober 2019 pukul 21.18 WIB.

2 Imam Al'Alamah TaqiyuddinIbnu Timiyah, Hukum-Hukum Perkawinan, (Jakarta:Pustaka Al-Kautsar,1997), hal. 15.
} 
kalimat "fankihu" kalimat amr (perintah) tersebut berfaedah mubah bukan wajib, yang dapat direlevansikan dengan kaidah ushul fiqh: al-asl fi al-amr al-Ibahah hatta Yadula dalilu 'ala attahrim (asal dari sesuatu itu boleh, kecuali ada dalil yang mengharamkannya). Dalam syariat Islam ,"Lebih disukai bila laki-laki hanya mempunyai seorang istri, bahkan kalau memungkinkan ia tetap mempertahankannya hingga akhir hayatnya."3 Hal tersebut karena perkawinan yang diajarkan Islam harus menciptakan suasana yang sakinah, mawaddah, warahmah. Suasana yang sulit dilaksanakan seandainya lakilaki memiliki istri lebih dari seorang. ${ }^{4}$

Poligami adalah seorang laki-laki beriistri lebih dari seorang tetapi dibatasi paling bannyak adalah empat orang. Karena lebih dari empat orang berarti mengingkari yang telah disyariatkan oleh Allah bagi kemaslahatan hidup suami istri. Allah SWT berfirman:

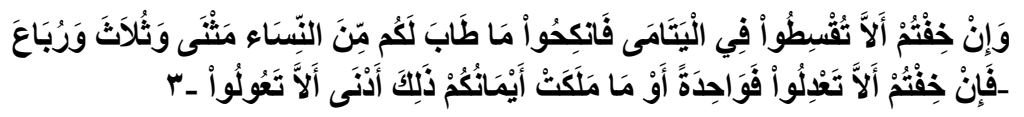

Artinya: "Dan jika kamu takut tidak akan dapat berlaku adil terhadap (hak-hak) perempuan yang yatim (bilamana kamu mengawininya) , maka kawinilah wanita-wanita (lain) yang kamu senangi:dua, tiga, atau empat. Kemudian jika kamu tidak akan dapat berlaku adil, maka (kawinilah) seorang saja, atau budak-budak yang kamu miliki. Yang demikian itu lebih dekat kepada tidak berbuat aniaya."

Dalam hukum Islam, poligami merupakan suatu proses kepemimpinan laki-laki atau suami dalam rumah tangganya. Apabila seorang suami yang pologini tidak mampu melaksanakan prinsip keadilan dalam rumah tangga , ia tidak

\footnotetext{
${ }^{3}$ LIHAT Rahmat Hakim, 200o, 113.

${ }^{4}$ Beni Ahmad Saebani, Fiqih Munakahat 2, (Bandung:Pustaka Setia,2016), hal.151.

${ }^{5}$ Slamet Abidin dan H.Aminuddin, Fiqih Munakahat 1, (Jakarta:Pustaka Setia, 2016), hal. 131.
} 
mungkin melaksanakan keadilan jika menjadi seorang pemimpin masyarakat.Jika seorang suami sewenang-wenang pada seoranng istri-istrinya, sebagai pemimpin, ia pun akan berbuat kezaliman kepada rakyatnya. Dalam surat Al-Nisâ ayat 3, bukan masalah poligininya yang penting, melainkan masalah keadilan dalam melaksanakan kepemimpinan dalam rumah tangga. Dalam hal itulah syariat Islam memberikann suatu gambaran bahwa poligami dapat dilakukan sejauh mungkin karena prinsip keadilannya. Muhammad Abduh mengatakan dalam tafsir al-Manar yang ditulis oleh Muhammad Rasyid Ridho (1970-109) "Meskipun agama Islam membuka jalan bagi poligami, jalan ittu sangat disempitkan , sehingga poligami itu hanya dapat dibenarkan dalam keadaan darurat. Oleh karena itu, poligami hanya diperbolehkan baagi oraang-orang yang terpaksa serta meyakini bahwa dia sanggup berlaku adil."

Islam memandang Poligami lebih banyak membawa resiko atau mudharat dari pada manfaatnya. Karena manusia itu menurut fitrahnya mempunyai watak cemburu, iri hati dan suka mengeluh. watak-watak tersebut akan mudah muncul dengan kadar tinggi, jika hidup dalam kadar kehidupan keluarga yang poligamis. dengan demikian poligamis itu bisa menjadi sumber konflik dalam kehidupan keluarga. Karena itu, hukum asal perkawinan itu adalah monogami.

Karena itu, poligami hanya diperbolehkan bila dalam keadaan darurat, misalnya istri dalam keadaan mandul. Maka dalam keadaan istri mandul dan suami bukan mandul berdasarkan keterangan medis laboratoris, suami diizinkan poligami dengan syarat ia benar-benar mencukupi nafkah semua keluarga dan harus bersifat adil dalam pemberian 
nafkah lahir batinnya serta giliran waktu tinggalnya, syaratsyarat material dan moral ${ }^{6}$.

Dalam firman Allah surat al-nisâ' ayat 2-3 disebutkan bahwa:

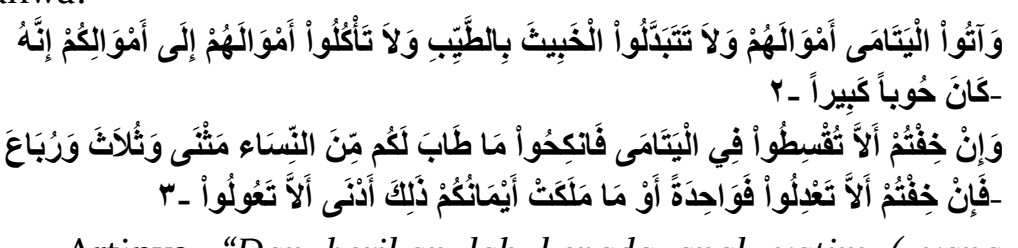

Artinya: "Dan berikan lah kepada anak yatim ( yang sudah baligh) harta mereka, jangan menukar yang baik dengan yang buruk dan jangan kamu makan harta mereka bersama hartamu. Sesungguhnya tindakantindakan (menukar dan memakan) itu adalah dosa yang besar. Dan jika kamu takut tidak akan dapat berlaku adil terhadap ( hak-hak) perempuan yatim (bila mana kamu mengawininya). maka kawinilah wanita-wanita (lain) yang kamu senangi: dua, tiga atau empat. Kemudian jika takut akan tidak dapat berlaku adil, maka ( kawinilah) seorang saja, atau budak-budak yang kamu miliki. Yang demikian itu adalah lebih dekat kepada tidak berbuat aniaya. “

Ayat tersebut menjelaskan bahwa para wali yang mengelola harta anak yatim itu akan berdosa besar jika sampai makan dan menukar harta anak yatim yang baik dengan yang jelek dengan jalan yang tidak sah; dan keada opara wali anak wanita yatim yang mau mengawininya, agar si wali itu ber'itikad baik, adil dan fair. ia tidak boleh mengawininya dengan maksud memeras dan menguras harta anak yatim atau menghalang-halangi anak yatim kawin dengan orang lain. jika wali anak yatim tersebut khawatir tidak bisa berbuat adil, maka ia tidak boleh mengawini anak yatim yang ada dibawah perwaliannya itu; tetapi ia wajib

\footnotetext{
${ }^{6}$ Rasyid Ridha, Tafsir al-Manar, vol. IV, (Mesir: Dar al-Manar, 1374 H), hal. 364-370.
} 
kawin dengan wanita lain yang ia senangi, satu sampai empat bila ia bisa berbuat adil. Tetapi bila ia tidak bisa berbuat adil, maka cukup satu saja, dan ia pun tidak boleh berbuat zhalim, maka ia tidak boleh kawin dengannya, tetapi ia mencukupkan dirinya dengan budak wanitanya.

Konteks ayat yang memperbolehkan poligami sesungguhnya lebih ditunjukkan pada upaya menyelamatkan kehidupan anak yatim sehingga bisa hidup secara layak. Dengan demikian mengawini ibu dari anak yatim bukanlah tujuan utama, sehingga isu krusial dalam al qur'an tentang poligami adalah keadilan kepada anak-anak yatim dari ibu yang dikawininya.

Menurut Rasyid Ridha maksud dari ayat tersebut ialah untuk memberantas atau melarang tradisi zaman jahiliyah yang tidak manusiawi, yaitu wali anak wanita yatim mengawini anak yatimnya tanpa memberi hak mahar dan hak-hak lainnya dan ia bermaksud untuk makan harta anak yatim dengan cara tidak sah, serta ia menghalangi anak yatimnya kawin dengan orang lain agar ia tetap leluasa menggunakan hartanya. Demikian pula pada zaman Jahiliyah yang mengawini istri banyak dengan perlakuan tidak adil dan tidak manusiawi, dilarang oleh islam berdasarkan ayat ini. Menurut al-Thabari, laki-laki yang mempunyai keyakinan bahwa dia akan dapat berlaku adil ketika berpoligami, maka ia boleh menikahi wanita maksimal empat wanita. Dan sebaliknya, laki-laki yang khawatir akan tidak dapat berlaku adil, maka ia cukup menikahi seorang wanita saja.

Menurut al-Jashashash, ayat tersebut berkaitan dengan anak yatim yang dinikahi dengan pengasuhnya. Pernikahan ini dilarang, ketika kecantikan dan harta anak yatim tersebut dijadikan alasan, karena dikhawatirkan wali tersebut memperlakukan wanita yatim yang berada dalam 
pengampuannya secara tidak adil, maka lebih baik wali tersebut menikah dengan wanita lain. Ayat ini juga merupakan ayat yang berupaya menghapuskan kebiasaan orang Arab, bahwa seorang wali tersebut berkuasa penuh terhadap wanita yatim yang diasuhnya, kalau ia cantik dan kaya maka dinikahinya, kalau ia kaya dan tidak cantik maka tidak dinikahinya dan laki-laki lainpun tidak boleh menikahinya, supaya wali itu bisa tetap menguasainya harta milik wanita yatim tersebut.

Poligami yang disebutkan dalam ayat tersebut hukumnya hanya mubah, dengan syarat berbuat adil terhadap para istri, baik dibidang kebutuhan materi seperti tempat tinggal, pemberian nafkah, dan pakaian maupun di bidang kebutuhan non- materi seperti kasih sayang dan kecenderungan hati.

Ayat diatas merupakan ayat yang sering digunakan untuk melegalkan poligami dalam islam. Persoalannya adalah benarkah ayat tersebut berbicara tentang kebolehan poligami? Dan benarkah islam melegalkan poligami?. Untuk menjelaskan permasalahan ini menurut Abu Yasid paling tidak ada tiga kelompok ulama yang dapat dikemukakan. Pertama, kelompok yang menafsirkan bahwa kawin berapapun jumlahnya diperbolehkan. Dalam hal ini ada beberapa argumentasi yang mereka kemukakan dalam mendukung pendapat mereka, yaitu (1) kalimat "al-Nisâ"” (perempuan) dalam ayat tersebut menunjukan bahwa bilangan yang banyak tanpa batas; (2) kalimat matsna (duadua), tsulatsa (tiga-tiga) dan ruba' (empat-empat) pada ayat tersebut tidak layak digunakansebagai alasan untuk mentakhsis (membatasi) bilangan perempuan yang boleh dikawini itu hanya sebatas empat orang saja kurang tepat. Karena dengan hanya mengkhususkan sebagian (menyebutkan 2, 3 dan 4 ), bukan berarti hukum sebagian lain (bilangan lebih 
dari empat) tidak berlaku lagi; (3) huruf wawu tersebut mengiddentifikasikan penjumlahan sehingga kawin sampai sembilan $(2+3+4)$ bahkan sampai delapan belas $(2+2+3+3+4+4)$ pun dipandang absah-absah saja;(4) alasan ini diperkuat dengan hadist yang menganjurkan untuk senantiasa mengikuti apa yang dilakukan oleh Rasulullah SAW. Sehingga dalam pemahaman mereka kawin lebih dari empat itu juga merupakan sunnah Rasulullah SAW.

Pendapat tersebut ditentang oleh kelompok kedua, dimana kelompok ini membatasi kebolehan ini mengawini wanita hanya sampai empat. Selain dengan pemahaman konvensional, mereka menolak penafsiran kelompok pertama, yang juga mendasarkannya pada kisah seorang sahabat yang bernama Ghailan. Sebelum masuk Islam, ia mempunyai istri sebanyak 10 orang. Kemudian setelah Ghailan masuk islam, Rosulullah menyuruhnya untuk menetapkan istrinya hanya batas empat saja. Hal ini juga dialami oleh shahabat Harits bin Qais al-Asadi, seorang shahabat yang memiliki delapan orang istri. Ketika ayat itu turun, Rosulullah memerintah shahabat Harits untuk mempertahankan empat dan menceraikan empat istri lainnya. Meskipun ada perbedaan penekanan diantara dua golongan diatas, namun memiliki titik kesimpulan yang sama, yaitu sama-sama membolehkan poligami, asalkan memenuhi persyaratan yang dikemukakan oleh Al-Qur'ân (bisa berlaku adil).

Menurut Syayid Qutub, poligami merupakan suatu perbuatan rukhsah yang dapat dilakukan hanya dalam keadaan darurat yang benar-benar mendesak. Kebolehan ini pun masih disyaratkan harus bisa berbuat adil terhadap isteriisteri di bidang nafkah, mu'amalah, pergaulan dan pembagian (waktu) malam. Bagi calon suami yang tidaksanggup berlaku 
adil, maka dicukupkan menikahi satu orang isteri saja. Sedangkan bagi calon suami sanggup berlaku adil, maka diperbolehkan menikahi isteri dengan batas maksimal empat orang saja.

Kelompok ketiga, diwakili oleh ulama kontemporer, diantaranya Muhammad Abduh. Menurut Muhammad Abduh, poligami hukumnya tidak boleh. Pada dasarnya, kelompok ini berpendapat bahwa hukum poligami itu boleh asalkan suami dapat berlaku adil. Yang menjadi persoalan sekarang ialah zaman sekarang sangat sulit bahkan tidak ada orang yang dapat berlaku adil kepada ister-isteri mereka. Banyak orang yang berpoligami yang meninggalkan isteri pertama mereka dan anak-anaknya. Isteri muda lebih mereka cintai diatas segalanya. Akibatnya, perhatian dan curahan kasih sayang mereka lebih fokus pada isteri muda. Keadilan yang dilakukan suami tidak hanya dalam hubungan seksual, tetapi pada akhirnya juga pada hal materi. Bahkan poligami itu hanya bertujuan untuk memuaskan hawa nafsu kaum lakilaki (suami) dan kebutuhan biologis, tanpa ada tanggung jawab penuh sebagai seorang suami.

Pada umumnya, para fuqaha dalam membahas masalah poligami hanya menyoroti aspek kebolehan poligami saja tanpa ada upaya untuk mengkritisi kembali hakikat dibalik hukum boleh tersebut secara historis, sosiologi maupun antropologis. Oleh karena itu, dalam perkembangannya kitab fiqh klasik hanya digugat karena dianggap bias gender.

Secara sosiologis, poligami dalam islam merupakan lompatan kebijakan sekaligus sebagai bahan koreksi islam atas syariat sebelumnya dan tradisi masyarakat Arab yang memperbolehkan menikah dengan wanita dengan perempuan tanpa batas. Faktor historis, membuktikan pada zaman Rasulullah SAW. Ada seorang sahabat yang bernama Ghailan al-Tsaqafi yang mempunyai sepuluh orang isteri, kemudian 
Rosulullah menyuruh nya untuk mengambil empat orang dari sepuluh isteri tersebut. Riwayat ini membuktikan bahwa poligami merupakann respon sosial maupun antropologis AlQur'ân terhadap budaya orang Arab.

Dalam menghadapi dan menyikapi persoalan tersebut ada beberapa pertimbangan yang perlu diperhatikan. Pertama, perlu kiranya melihat sebab-sebab yang melatarbelakangi turunnya ayat tersebut (asbabun nuzul). Diantara sebab yang melatarbelakangi turunnya ayat tersebut adalah bahwa ketika Rasulullah diutus, kaum Quraisy masih menjalankan tradisi mereka sebelumnya, termasuk kawin lebih dari empat orang. Beliau hanya memerintah atau melarang suatu perbuatan, tetapi tidak pernah mengungkitungkit tradisi mereka.

\section{Pembahasan}

\section{Alasan, Syarat, dan Prosedur Poligami}

a. Alasan Poligami

Asal perkawinan adalah seorang suami utuk seorang istri. Sedangkan poligami bukan pokok, tetapi keluarbiasaan atau ketidakwajaran yang dilakuka karena kondisi darurat. Yang dimaksud dengan kondisi darurat adalah adanyaa alasan logis yang secara normatif dapat dibenarkan. Dalam syariat Islam, poligami disebabkaan oleh beberapa hal yang wajar, yaiitu:

1) Terhalangnya reproduksi generatif, misalnya kemandulan,

2) Istri tidak berfungsi sebagai istri,

3) Suami yang hiperseks sehingga membutuhkan penyaluran yang lebih dari seorang istri,

4) Jumlah perempuan melebihi laki-laki; dan 
5) Istri yang menyuruh suaminya untuk berpoligami (jumlah terkecil di dunia) $^{7}$

Dengan adanya sistem poligami dan ketentuannya dalam dunia Islam, merupakan satu karunia besar bagi kelestariannya, yang menghindari dari perbuatanperbuatan sosial yang kotor dan akhlak yang rendah dalam masyarakat yang mengakui poligami. Adapun dalam masyarakat yang melarang poligami dapat dilihat hal-hal sebagai berikut.

a) Kejahatan dan pelacuran tersebar dimana-mana, sehingga jumlah pelacur lebih banyak daripada perempuan yang bersuami.

b) Banyak anak-anak yang kahir tanpa ayah yang jelas , sebagai hasil dari perbuatan di luar nikah.

c) Munculnya bermacam-macam penyakit badan, kegoncangaan mental dan gangguan, gangguan syaraf.

d) Mengakibatkan keruntuhan mental

e) Merusak hubungan yang sehat suami dan istri, mengganggu kehidupan rumah tangga dan memutuskan tali ikatan kekeluargaan, sehingga tidak lagi menganggap segala sesuatunya berharga dalam kehidupan bersuami istri.

f) Meragukan sahnya keturunan, sehingga suami tidak yakin bahwa anakanak yang diasuh dan dididik adalah darah dagingnya sendiri. ${ }^{8}$

b. Syarat Poligami

Dalam ayat Al-Qur'ân juga menerangkan tentang syarat-syarat melakukan poligami, yaitu:

\footnotetext{
7 Beni Ahmad Saebani, Fiqih Munakahat 2(Bandung:Pustaka Setia,2016),hlm.152. lihat Rahmat Hakim, 2000:116-119,

${ }^{8}$ Slamet Abidin dan H.Aminuddin , Fiqih Munakahat 1, (Jakarta: Pustaka Setia, 2016), hal. 133-134.
} 
1) Mampu berbuat adil kepada semua istrinya

Dalilnya adalah firman Allah SWT. Surat AlNisâ': 3 yang artinya” kemudian jika kamu takut tidak dapat berlaku adil, maka kawinilah satu orang saja”.

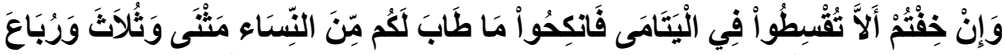

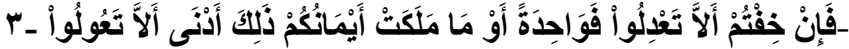
Artinya:"Dan jika kamu takut tidak akan dapat berlaku adil terhadap (hak-hak) perempuan yang yatim (bilamana kamu mengawininya), maka kawinilah wanita-wanita (lain) yang kamu senangi:dua, tiga, atau empat. Kemudian jika kamu tidak akan dapat berlaku adil , maka (kawinilah) seorang saja, atau budak-budak yang kamu miliki. Yang demikian itu lebih dekat kepada tidak berbuat aniaya."

2) Mampu menjaga diri untuk tidak terpedaya dengan istri-istrinya itu dan tidak meninggalkan hak-hak Allah karena keberadaan mereka.

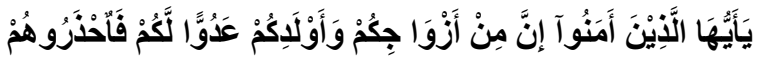

Allah berfirman," Hai orang-orang yang beriman, sesunggguhnya diantara istri-istrimu dan anakanakmu ada yang menjadi musuh bagimu, maka berhati-hatilah kamu terhadap mereka."

3) Memiliki kemampuan untuk memenuhi kebutuhankebutuhan lahirlah dan menjaga kehormatan mereka. Hal ini bertujuan agar istri-istrinya itu terhindar dari kenistaan dan kerusakan, karena Allah tidak mempunyai kerusakan. Dalam sebuah hadits, Nabi saw, Bersabda:

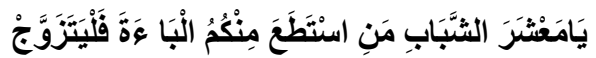

“Hai segenap pemuda, siapa diantara kalian sanggup 
menikah, maka menikahlah.” (Muttafaq'alaih)

4) Memiliki kesanggupan untuk memberi nafkah kepada mereka. Allah swt. Berfirman,” dan orang-orang yang tidak mampu kawin hendaklah menjaga kesucian (dirinya), sehingga Allah membuat mereka mampu dengan karunia-Nya." (An-Nûr:33)

Selain alasan diatas, syarat-syarat untuk berpoligami menurut ketentuan pasal 5 Undang-undang perkawinan juga harus dipenuhi yaitu:

1) Untuk dapat mengajukan permohonan kepada pengadilan, sebagaimana dimaksud dalam pasal 4 ayat (1) undang-undang ini, harus dipenuhi syaratsyarat sebagai berikut:

a. Adanya persetujuan dari isteri/isteri-isteri.

b. Adanya kepastian bahwa suami mampu menjamin keperluan-keperluan hidup isteriisteri dan anak-anak mereka.

c. Adanya jaminan bahwa suami akan berlaku adil terhadap isteri-isteri dan anak-anak mereka.

2) Persetujuan yang dimaksud pada ayat (1) huruf a pasal ini tidak diperlukan bagi seorang suami apabila istri-istrinya tidak mungkin diminta persetujuannya dan tidak dapat menjadi pihak dalam perjanjian,atau apabila tidak ada kabar dari istrinya selama sekurang-kurangnya 2 (dua) tahun, atau karna sebab-sebab lainya yang perlu mendapat penelitian dari hakim pengadilan. Untuk melihat perbedaan antara pasal 4 dan pasal 5 adalah, pada pasal 4 disebut dengan persyaratan alternatif yang artinya salah satu harus ada untuk dapat mengajukan permohonan poligami. Sedangkan pasal 5 adalah pernyataan komulatif dimana seluruhnya harus 
dapat dipenuhi suami yang akan melakukan poligami.

Dalam Kompilasi Hukum Islam syarat poligami di jelaskan dalam pasal 55 yang berbunyi:

1) Beristri lebih dari satu orang pada waktu bersamaan terbatas hanya sampai 4 orang istri.

2) Syarat utama beristri lebih dari seorang, suami harus berlaku adil terhadap isteri-isteri dan anak-anaknya.

3) Apabila syarat utama yang disebut dalam ayat (2) tidak mungkin dipenuhi suami dilarang beristri lebih dari seorang.

Syarat yang lain disebutkan pasal 58 ayat 1 Kompilasi Hukum Islam, selain syarat utama yang di sebut pasal 55 ayat 2 maka untuk memperoleh izin pengadilan agama harus pula dipenuhi syarat-syarat yang ditentukan pada pasal 5 Undang-undang ayat 1 tahun 1974 yaitu:

a. Adanya persetjuan isteri

b. Adanya kepastian bahwa suami mampu menjamin keperluan hidup isteri-isteri dan anak-anak mereka.

c. Prosedur Poligami

Mengenai prosedur atau tata cara poligami yang resmi diatur oleh islam memang tidak ada ketentuan secara pasti namun diindonesia dalam Kompilasi Hukum Islam telah mengatur hal tersebut sebagai berikut:

Pasal 56 berbunyi:

a) Suami yang hendak beristeri lebih satu orang harus mendapatkan izin dari pengadilan agama.

b) Pengajuan permohonan izin dimaksud pada ayat $1 \mathrm{di}$ lakukan menurut tata cara sebagaimana di atur dalam bab VIII peraturan pemerintah no 9 tahun 1975. 
c) Perkawinan yang dilakukan dengan isteri ke dua, keiga atau keempat tanpa izin dari pengadilan agama, tidak mempunyai kekuatan hukum.

Pengadilan agama hanya memberi izin kepada seorang suami yang akan lebih beristeri lebiih dari seorang dalam pasal 57 Kompilasi Hukum Islam apabila :

a. Isteri dapat menjalankan kewajiban sebagai isteri

b. Isteri mendapat cacat badan atau penyakit yang tidak dapat di sembuhkan.

c. Isteri tidak dapat melahirkan keturunan.

Jika pengadilan agama sudah menerima perizinan poligami, kemudian ia memeriksa berdasarkan pasal 57 $\mathrm{KHI}$

a. Ada atau tidaknya alasan yang memungkinkan seorang suami kawin lagi

b. Ada atau tidaknya persetujuan dari istri, baik persetujuan lisan maupun tulisan, apabila persetujuan itu merupakan persetujuan lisan, persetujuan itu harus diucapkan di depan pengadilan.

c. Ada atau tidaknya kemampuan suami untuk menjamin keperluan hidup istri istri dan anak - anak dengan memperlihatkan

1) Surat keterangan mengenai penghasilan suami yang di tanda tanggani oleh bendahara tempat bekerja

2) Surat keterangan pajak penghasilan

3) Surat keterangan lain yang dapat diterima oleh pengadilan

Pasal 58 ayat (2) KHI

Dengan tidak mengurangi ketentuan pasal 41 huruf $b$ peraturan pemerintah nomor 9 tahun 1975 . Persetujuan istri atau istri-istri dapat diberikan secara 
tertulis atau dengan lisan, tetapi sekalipun telah ada persetujuan tertulis, persetujuan ini dipertegas dengan persetujuan lisan istri pada siding pengadilan Agama

Adapun tata cara teknis pemeriksaanya menurut pasal 42 pp nomor 9 tahun 1975 adalah sebagai berikut:

(1) Dalam melakukan pemeriksaan mengenai hal -hal dalam pada pasal 40 dan 41. Pengadilan harus memanggil dan mendengar istri.

(2) Pemeriksaan pengadilan untuk itu dilakukan oleh hakim selambat-lambatnya 30 hari setelah diterima surat permohonan beserta lampiranya. ${ }^{9}$

\section{Asas Monogami dan Dasar Hukum Poligami}

a) Asas Monogami

Asas monogami menganut dalam UU Nomor 1 Tahnu 1974 tentang perkawinan. Burgelijk Wetboek (Kitab Undang-Undang Hukum Perdata) juga menganut asas monogami. Namun latar belakang berlakunya asa monogami pada kedua peraturan tersebut berbeda. Burgeljik Wetboek menganut asas monogammi karena dilatarbelakangi oleh pandangan agama kristen.Dalam pandanga umat nasrani, perkawinan adalah sebuah sakreamen, sehingga ikatan tersebut tidak dapat diputuskan oleh manusia.Hanya kematian yang dapat mengakhiri perkawinan. Sedangkan berlakunya asas monogami pada UU perkawinan dilatarbelakangi oleh perjuangan wanita Indonesia yang berupaya untuk melindungi kaum mereka dari praktik Monogami.

9 Ny.Soemiyati, Hukum Perkawinan Islam dan Undang-Undang Perkawinan : UndangUndang No.1 Tahun 1974,tentang perkawinan, (Yogyakarata:Liberty Yogyakarta,1982), hal. $47-48$. 
Asa Monogami dalam UU Perkawinan tampak jelas dalam pasal 3 ayat (1) UU Perkawinan yang menentukan bahwa pada asaanya dalam suatu perkawinan seorang pria hanya boleh mempunyai seorang istri dan seorang wanita hanya boleh mempunyai seorang suami.Namun, dalam ayat (2) ketentuan tersebut membuka peluang bagi seorang suami untuk berpoligami. Pasal 3 ayat (2) UU Perkawinan menentukan bahwa pengadilan dapat memberi izin kepada seorang suami untuk beristri lebih dari seorang apabila dikehendaki oleh pihak-pihak yang bersangkutan. ${ }^{10}$

Dasar hukum Islam ada dua, yakni Al-Qur'an dan As-Sunnah ${ }^{11}$ Akan tetapi , ulama Syafiiyah menetapkan bahwa dasar hukum Islam ada empat, yaakni Al-Qur'an, As-Sunnah, Ijma', Qiyas (Fathurahman dan Mukhtar Yahya, 1989:34). Sesungguhnya dasar hukum merupakan pijjalkan yang dijadian tempat keluarnya sesuatu ketentuan yang berlaku untuk perbuatan tertentu.A.Djazuli (2000:23) mengatakan bahwa dasar hukum dalam Islam adalah Al-Qur'ân dan As-Sunnah , tetapi ijma' sahabat dapat dijadikan dasar hukum, sedangkan qiyas dan yang lainnya adalah metoode untuk mengeluarkan kandungan hukum yang terdapat dalam Al-Qur'ân maupun Al-Hadits :

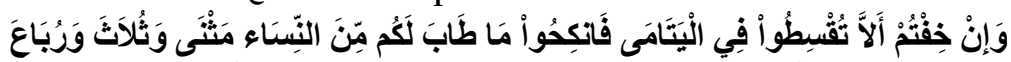

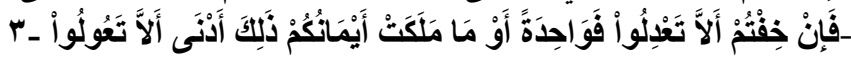

Artinya: "Dan jika kamu takut tidak akan dapat berlaku adil terhadap (hak-hak) perempuan yang yatim (bilamana kamu mengawininya), maka kawinilah

\footnotetext{
10 https//www.jurnalhukum.com/asas-monogami-dan-izin-berpoligami-dalamperkawinaan./ pada tanggal 10 Oktober 2019 pada pukul 07.10

${ }^{11}$ Lihat Moenawar Kholil, 1989, 11.
} 
wanita-wanita (lain) yang kamu senangi:dua, tiga, atau empat. Kemudian jika kamu tidak akan dapat berlaku adil , maka (kawinilah) seorang saja, atau budak-budak yang kamu miliki. Yang demikian itu lebih dekat kepada tidak berbuat aniaya."

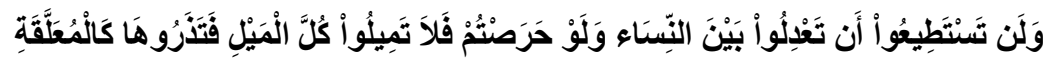

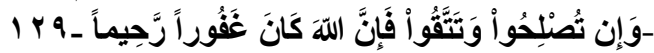
Artinya:"Dan kamu sekali-kali tidak akan dapat berlaku adil di antara istri-istri (mu) walaupun kamu sangat ingin berbuat demikian, karena itu janganlah kamu terlalu cenderung (kepada yang kamu cintai) sehingga kamu biarkan yang lain terkarung-katung dan jika kamu mengadakan perbaikan dan memelihara diri (dari kecurangan), maka sesungguhnya Allah maha pengampun lagi maha penyayang."

Ayat tersebut menegaskan bahwa keadilan tidak mungkin dapat dicapai jika berkaitan dengan perasaan atau hati dan emosi cinta. Keadilan yang harus dicapai adalah keadilan materiil semata-mata, sehingga seorang suami yang poligami harus menjamin kesejahteraan istri-istrinya dan mengatur waktu gilir secara adil. ${ }^{12}$ mengatakan bahwa surat Al-Nisâ ayat 129 meniadakan kesanggupan berlaku adil kepada sesama istri. Sedangkan ayat sebelumnya (Al-Nisâ ayat 3) memerintahkan berlaku adil. Dengan demikian, seolaholah ayat tersebut bertentangan satu sama lainnya. Padahal, tidak terdapat pertentangan dalam ayat yang dimaksud. Kedua ayat tersebut menyuruh berlaku adil dalam hal pengaturan nafkah keluarga, pengaturan kebutuhan sandaang, pangan dan papan, sehingga bagi

\footnotetext{
${ }^{12}$ Lihat juga Sayyid Sabiq, 1987, 172.
} 
suami yang poligami tidak perlu memaksakan dalam soal perasaan , cinta dan kasih sayang, karena semua itu diluar kemampuan manusia. Hadits Riwayat Imam Tirmidzi

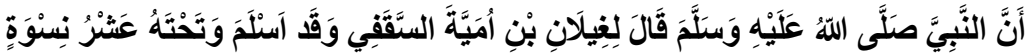

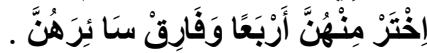 \\ Artinya: "Dari Ibnu Umar RA bahwa Ghailan bin Salamah As-Saaqafi telah masuk Islam. Ketika masih jahiliah ia mempunyai sepuluh iatri, istri-istrinya masuk islam beserta dia, lalu dia disuruh oleh Rasulullah SAW. Memilih empat istri diantara mereka (yang enam diceraikan)."( HR Tirmidzi) ${ }^{13}$}

\section{Hikmah dan Dampak Negatif Poligami}

Karena tuntutan pembangunnan, undang-undang diperbolehkannya poligami tidak boleh diabaikan begitu saja, walaupun hukumnya tidak wajib, dan juga tidak sunnah.

Hikmah poligami antara lain : Untuk mendapatkan ketururnan bagi suami yang subur dan istri yang mandul, untuk menjaga keutuhan keluarga tanpa menceraikan istri, sekalipun istri tidak mampu menjalankan tugasnya sebagai istri, atau ia mendapat cacat, penyakit yang tidak dapat disembuhkan, untuk menyelamatkan suami yang hypersex dari perbuatan zina dan krisis akhlak lainnya dan untuk menyellamatkan kaum wanita dari krisis akhlak yang tinggal di negeri yang jumlah wanitanya lebih banyak dari kaum prianya.

Dampak Negatif Poligami antara lain : Poligami dapat menimbulkan kecemburuan diantara para istri dan menimbulkan rasa kekhawatiran istri, kalau-kalau suami tidak bisa bersikap adil dan bijaksana, Anak-anak yang dilahirkan dari Ibu yang berlainan sangat rawa untuk terjadinya perkelahian, permusuhan dan saling cemburu dan

${ }^{13}$ Lihat juga Fuad Adb Al-baqi, t.t.:628 
kekacauan dalam bidang ekonomi, bisa saja pada awalnnya suami memiliki kemampuan untuk poligami, namun tidak mustahil suatu saat akan mengalami kebangkrutan.

Sedangkan dari sisi monogami tidak terlalu banyak dampak yang disebabkan.Karena hammpir seluruh pasangan yang melakukan monogami, tapi jika disinggung dengan halhal di atas yang berkaitan monogami bisa juga menyebabkan terjadinya perselingkuhan daan kekerasan dalam rumah tangga.

\section{Penutup}

Penulis mencoba mensikapi masalah poligami secara wajar karena Allah dan Rasul-Nya tidak pernah melarang poligami, maka penulis sepakat dengan para ulama yang tidak mengharamkan poligami. Namun yang harus menjadi acuan di sini adalah bahwa semua ketentuan hukum Allah (hukum Islam) adalah untuk kemaslahatan umat manusia. maka jelaslah bahwa disyariatkannya poligami juga demi kemaslahatan manusia. Karena itu, siapa pun boleh melakukan poligami selama kemaslahatan itu bisa diwujudkan. Namun, jika kemaslahatan itu tidak bisa terwujud ketika orang melakukan poligami, maka poligami tidak boleh dilakukan.

Persyaratan yang ditentukan oleh al-Qurân (seperti keharusan berlaku adil) dan juga berbagai ketentuan yang ditetapkan oleh para ulama tentang poligami yang harus dipahami sebagai upaya untuk mewujudkan kemaslahatan dalam pelaksanaan poligami. Penulis tidak setuju dengan 
praktik poligami yang hanya sekedar untuk kesenangan belaka atau untuk mempermainkan perempuan.

Dalam perundang-undangan Indonesia, masalah poligami diatur dalam UU No. 1/1974. Seseorang boleh melakukan poligami apabila dipenuhi persyaratannya dan diputuskan oleh pengadilan dan batasan poligami dalam hukum islam diperbolehkan dengan syarat hanya dibatasi dengan empat orang istri dan dapat berlaku adil terhadap istri-istrinya.

\section{Daftar Pustaka}

Jones, Jamilah, Abu Aminah Bilal Philips, Monogami dan Poligini Dalam Islam (Jakarta:PT Rajagrafindo Persadam 2001).

Hakim,Rahmat, Hukum Perkawinan Islam (Bandung: Pustaka Setia 200o).

Rahman I, Abdur, Perkawinan dalam Syariat Islam (Jakarta:PT Rineka Cipta, 1992).

Saebani, Beni Ahmad, Fiqh Munakahat 2 (Bandung:Pustaka Setia, 2016).

Abidin,Slamet, Aminuddin, Fiqh Munakahat 1 (Bandung:Pustaka Setia 2016).

Ali,Zainuddin, Hukum Perdata Islam di Indonesia (Jakarta:Sinar Grafika, 2006).

Soemiyati.1982.Hukum Perkawinan Islam dan Undang-Undang Perkawinan( Undang-Undang No.1 Tahun 1974, tentang Perkawinan).Yogyakarta:Liberty, Yogyakarta).

https://id.scribd.com/document/343228805/makalahmonogami, 21.18 WIB.

Timiyah,Imam Al'Alamah Taqiyuddin Ibnu, Hukum-Hukum Perkawinan (Jakarta:Pustaka Al-Kautsar, 1997).

Aibak,Kutbuddin, Kajian Fiqh Kontemporer (Sleman Yogyakarta:Kalimedia 2017).

https;//www.jurnalhukum.com/asas-monogami-dan-izinberpoligami-dalam-perkawinan/ 